\title{
İŞLETMELERDE İNOVASYONA ETKİ EDEN FAKTÖRLER: KARAMAN İLİ ÖRNEĞí
}

\author{
Kerim ÇETIN \\ KTO Karatay Üniversitesi, (kcetin70@gmail.com) \\ Yar. Doç. Dr. Hasan GEDIK \\ KTO Karatay Üniversitesi, (hasan.gedik@karatay.edu.tr)
}

\begin{abstract}
ÖZET
Sürekli değişim ve yoğun rekabet ortamında, işletmeler için inovasyonun önemi her geçen gün artmaktadır. Işletmelerde verimlilik artışı ve sürdürülebilir karlılı̆̆ sağlayabilmek, küreselleşen piyasalarda inovasyon uygulamalarıyla mümkün olabilmektedir. İsletmelerin inovasyon faaliyetlerini etkileyen faktörlerin analizi amacıyla, inovasyon yapmada işletme yaşı ve işletmede çalışan sayısının etkisini araştırmak üzere, Karaman ilinde anket yoluyla veriler toplanmıştır. Doğrusal regresyonla hipotezler test edilmiş, veriler yorumlanmıştır. Analiz sonucunda inovasyon yapma ile işletme yaşı arasında anlamlı bir iliş̧i bulunamamış, işletmede çalışan saylslyla anlaml bir ilişki bulunmuştur. Inovasyon yapma, işletmenin özelliklerine, sektörüne, büyüklügüne, bölgesel ve içsel-dişsal faktörlere göre değişebilmektedir. Analiz sonuçları değişkenlik gösterebilmektedir.
\end{abstract}

Anahtar Kelimeler: Inovasyon, Karlılık, Pazarlama, Ekonomi, Karaman

\section{THE FACTORS AFFECTING INNOVATION IN ENTERPRISES: SAMPLE OF KARAMAN}

\begin{abstract}
The importance of innovation for enterprises in continuous change and intensive competitive environment is increasing day by day. To increase productivity and sustainable profitability can be possible with innovation practices in global markets. For the purpose of analysis of innovation activities for enterprises, the datas were collected through a survey in Karaman to research the effects of the age of enterprise and the number of employees for innovation. Hypothesis were tested with linear regression and interpreted. As a result of analysis, there is not a significant relationship between the age of enterprise and innovation. But there is a significant relationship between the number of employees and innovation. Innovation can be change according to the features of enterprises, size of the sector, local and internal-external factors. The result of analysis can be variable.
\end{abstract}

Keywords: Innovation, Profitability, Marketing, Economy, Karaman. 


\section{Giriş ve Çalışmanın Amacı:}

İşletmeler için inovasyon, maliyetleri minimize etme, karlılığı sürdürülebilir şekilde yükseltme, kaliteli standart ürünle hizmet sunabilme ve tüm yönetsel süreçleri iyileştirme firsatı olarak görülebilir. Bu anlamda inovasyon, işletmelerin üründe, süreçte, pazarlamada, organizasyonel faaliyetlerinde yenilenme ile ticari fayda oluşturan girişimlerinin sonucudur.

Ekonomik kalkınmada inovasyon önemi her geçen gün daha etkili olmaktadır. Yenilik girişimlerinin çıktısına bakıldığında, inovasyon karnesi olarak, 2017 yılında Küresel İnovasyon Endeksi Raporunda, 138 ülke arasında Türkiye 38,9 puan ile 43. sırada yer almıştır. Küreselleşen dünyada, yüksek yaşam standartlarına ulaşabilmek, yüksek karlılık ve ekonomik gelişmeyi sağlayabilmek, yüksek rekabet gücünü bağlı olmakla beraber, rekabet üstünlüğü sağlayabilmenin altın anahtarı ise inovasyon olarak görülmektedir. Bu anlamda, işletmelerde başarı için yenilik ve sürekli değişim yapmak kaçınılmaz bir zorunluluk haline gelmektedir (Küresel İnovasyon Endeksi 2017 Raporu).

$\mathrm{Bu}$ araştırma, Karaman ilinde faaliyet gösteren firmalarda, inovasyon yapmada işletmedeki çalışan sayısı ve işletme yaşının etkilerini incelemeyi amaçlamaktadır. İşletmelerdeki inovasyona etki eden faktörler, inovasyon yapma nedenleri ve inovasyon engelleri incelenmiştir.

\section{2. İnovasyon (Yenilik):}

İnovasyonun tanımında farklı yaklaşımlar olsa da firma gözünden bakıldığında tüm tanımların temeli “firmalara ticari başarı kazandıran yenilikler” olarak karşımıza çıkmaktadır (Turanlı \& Sarıdoğan, 2010: 14-15).

Genel anlamda "yenilikçi fikirlerin katma değerli çıktılara dönüştürülme süreci” olarak tanımlanan inovasyon, "katma değer oluşturmak amaciyla, yeni ürün, hizmet, süreç, iş modeli, fikirlerin uygulamaya konulmasıdır"' (www.smenetworking.gov.tr).

İnovasyon (Yenilik) : “İşletme için uygulamalarda, işyeri organizasyonunda veya dış ilişkilerde yeni veya önemli derecede iyileştirilmiş bir ürün (mal veya hizmet), veya süreç, yeni bir pazarlama yöntemi ya da yeni bir organizasyonel yöntemin gerçekleştirilmesidir.' Tanımda vurgu yapılan nokta inovasyonun, firma için "pazarlanabilir olması" ve "yeni veya önemli derecede iyileştirilmiş" ürün veya süreçleri bulundurmasıdır (OECD-EUROSTAT, 2005: 50).

"İnovasyon (Yenilik): Sosyal ve ekonomik ihtiyaçlara cevap verebilen, mevcut pazarlara başarıyla sunulabilecek ya da yeni pazarlar yaratabilecek; yeni bir ürün, hizmet, uygulama, yöntem veya iş modeli fikri ile oluşturulan süreçleri ve sonuçlarını', ifade etmektedir. KOSGEB, 2016.

İnovasyon, "iktisatçılar tarafından yeni bir ürün veya üretim sürecinin ilk ticari uygulaması veya üretimi şeklinde tanımlandığı için, buradan girişimcinin yeni fikirlerle piyasaları bağlamada çok kritik bir katkısı olduğu ortaya çıkmaktadır''(Freeman \& Soete, 2004: 233).

\section{1 İnovasyon Türleri:}

Ana kullanım amaçlarına göre Oslo Kılavuzu'nda (2005), yeniliklerde belli bir standartı sağlayabilmek için ağırlıklı dört inovasyon türü üzerinde durulmuştur. Bu inovasyonlar;

- Ürün inovasyonu,

- Süreç inovasyonu,

- Pazarlama inovasyonu,

- Organizayonel inovasyon

olarak belirlenmiştir.

“İnovasyon, bir fikrin pazarlanabilir bir ürün veya hizmete, yeni veya geliştirilmiş bir üretim süreci veya dağıtım yöntemine dönüşümünü kapsar. Diğer bir ifadeyle işletmeler inovasyonu

- Ürettikleri mal ve hizmette,

- Üretim süreçlerinde,

- Yönetim tekniklerinde,

- Pazarlama yöntemlerinde

uygulayıp gerçekleştirebilirler', (www.abigem.org).

\section{2. Ürün İnovasyonu:}

Ürün inovasyonu, "mevcut özellikleri veya öngörülen kullanımlarına göre yeni ya da önemli derecede iyileştirilmiş bir mal veya hizmetin ortaya konulmasıdır. Bu; teknik özelliklerde, bileşenler ve malzemelerde, 
birleştirilmiş yazılımda, kullanıcıya kolaylığında ve diğer işlevsel özelliklerinde önemli derecede iyileştirmeleri içermektedir" (OECD-EUROSTAT, 2005: 52).

\subsection{Süreç İnovasyonu:}

Süreç inovasyonu, "yeni veya önemli derecede iyileştirilmiş bir üretim veya teslimat yönteminin gerçekleştirilmesidir. Bu yenilik, teknikler, teçhizat ve/veya yazılımlarda önemli değişiklikler içermektedir. Süreç yenilikleri, birim üretim veya teslimat maliyetlerinin azaltmak, kaliteyi artırmak veya yeni ya da önemli derecede iyileștirilmiş ürünler üretmek veya teslim etmek üzere öngörülebilir" ş̧ekilde tanımlanmaktadır (OECDEUROSTAT, 2005: 53).

\subsection{Pazarlama İnovasyonu:}

Oslo Kılavuzuna göre, pazarlama inovasyonu, “ürün tasarımı veya ambalajlanması, ürün konumlandırması, ürün tanıtımı (promosyonu) veya fiyatlandırmasında önemli değişiklikleri kapsayan yeni bir pazarlama yöntemidir. Pazarlama yenilikleri firmanın satışlarını artırmak amacıyla, müşteri ihtiyaçlarına daha başarılı şekilde cevap vermeyi, yeni pazarlar açmayı veya bir firma ürününü pazarda yeni bir şekilde konumlandırmayı hedeflemektedir' (OECD-EUROSTAT, 2005: 53).

\subsection{Organizasyonel İnovasyon:}

Oslo Kılavuzu (2005) 'e göre, "Bir organizasyonel yenilik, firmanın ticari uygulamalarında, işyeri organizasyonunda veya dış ilişkilerinde yeni bir organizasyonel yöntem uygulanmasıdır. Organizasyonel yeniliklerin, idari maliyetlerini ve işlem maliyetlerini düşürmek, işyeri memnuniyetini (ve dolayısıyla işçilik üretkenliğini) iyileştirmek, ticari olmayan varlıklara (düzenlenmemiş dış bilgiler gibi) erişim kazanmak ya da araç gereç maliyetlerini düşürmek suretiyle firma performansının artııılması öngörülebilir" (OECD-EUROSTAT, 2005: 55).

\section{3. İnovasyonun Önemi:}

Günümüz rekabet ortamında üretim maliyetlerin yanında müşteri ihtiyaçları ve talepleri de işletmeleri inovasyon yapmaya zorlamaktadır. Firmalar daha az girdi ile daha çok kaliteli ve daha çok verimli ürün ya da hizmet sunma çabası içerisindedir. Sarfedilen çabalar sayesinde inovasyonlar, işletmelerin pazardaki gücünü geliştirip daha fazla yeni pazarlar bulmasını sağlayacaktır. Yeni iş firsatları ile "sektörü ve büyüklüğü ne olursa olsun tüm firmaların inovasyon yapması kaçınılmazdır"' (Elçi, 2006: 31-32).

Genel olarak işletmeler için inovasyon "sürdürülebilir büyüme aracı" olarak görülmektedir. "İşletmeler için inovasyon yapmanın önemini" ş̧öyle belirtilmiştir (www.fka.gov.tr):

- 'Verimiliğin artması

- Rekabet üstünlüğ̈̈

- Ödemler dengesizliğinin giderilmesi

- Sosyal sorumluluk bilincinin gelişimi

- Sadık müşteri bilinci

- Kurumsallaşma ve markalaşma

- Araştırma ve geliştirmeye yöneltme"

Westland (2008) 'e göre, inovasyon, icat ve ticari başarının toplamıdır. Trott (2005) 'a göre, inovasyon, teorik konsept, teknik icat ve ticari başarının toplamıdır. Her iki tanımda da yeniliğin, değişimin kaçınılmaz olduğu ve ticari faydanın bir değer oluşturulduğu görülmektedir.

Küreselleşme ortamında, rekabet üstünlüğü elde edebilmek, " en az girdi ile en fazla katma değeri yaratabilme" becerisi ile mümkün olabilmektedir. Yüksek verimlilik için maliyetlerde tasarruf yababilmeliyiz. Bunun en etkili yolu ise, her süreçte ve her koşulda sürekli bir şekilde inovasyon yapabilmekten geçmektedir (Arslan, 2008: 104).

TÜIK (2014) yenilik araştırmasına göre, Türkiye'de “girişimlerin \%38'i 2012-2014 yıllarını kapsayan üç yıllık dönemde ürün ve/veya süreç yeniliği faaliyetinde (devam eden ve sonuçsuz kalan yenilik faaliyetleri de dahil) bulundu. Aynı dönem içerisinde yenilik faaliyeti devam eden girişimlerin oranı $\% 20,4$, yenilik faaliyeti sonuçsuz kalan girişimlerin oranı ise \%5,5 oldu. Girişimlerin \%41'i 2012-2014 yıllarını kapsayan üç yıllık dönemde organizasyon ve/veya pazarlama yeniliği faaliyetinde bulundu. Bu kapsamda girişimlerin \%28,5'i organizasyon yeniliği, \%33,6'sı ise pazarlama yeniliği gerçekleştirdi”" (TÜiK, Ekim 2015). 
Şekil 1. Temel Yenilik Göstergeleri (2012-2014)

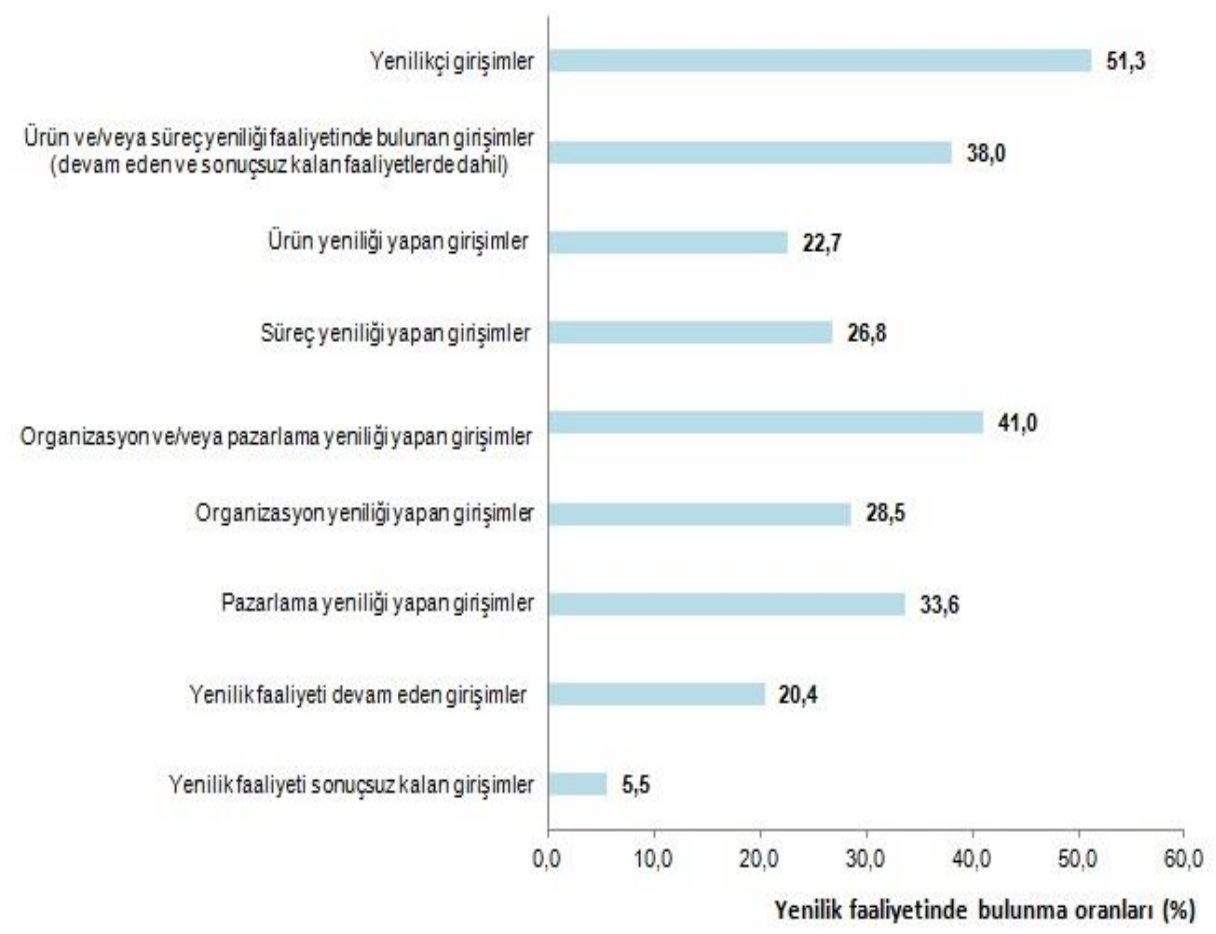

Kaynak: TÜiK (http://www.tuik.gov.tr/PreHaberBultenleri.do?id=18662)

\section{1. İnovasyon Yapma Nedenleri:}

İnovasyon yapma nedenleri genel olarak "pazar/tüketici ihtiyaçlarını tahmin etmek ve bu ihtiyaçları yeni ürünler, hizmetler ve üstün kaliteyle sürekli tatmin etmek" olarak karşımıza çıkmaktadır. Bu ihtiyaçları giderirken "tüketici, rekabet, toplum ve organizasyon" faktörleri ile işbirliği yapmak esastır (www.northstarinnovation.com.tr).

İnovasyon yapma nedenleri şöyle belirtilebilir (Yapar, 2015):

- Pazar payını artırmak

- Ürün ve hizmet kalitesini artırmak

- Düzenleme ve standartlara uymak

- Üretim esnekliği sağlanması

- İşçi maliyetlerinin düşürülmesi

- Malzeme tüketiminin azaltılmas

- Enerji tasarrufu

- Çevrenin korunması

- Müşteri isteklerinin değişmesi

- Teknolojik gelişmeler

- Rakiplerin inovasyon faaliyetleri

\section{2. İnovasyon Yapmadaki Engeller:}

Oslo kılavuzuna (2005) göre inovasyon yapmaya engel olan ya da engel olabilecek faktörler şöyle belirtilmiştir (OECD-EUROSTAT, 2005: 117):

\subsubsection{Maliyet faktörleri:}

- $\quad$ Riski yüksek görme

- Maliyetlerin çok fazla olması

- Girişim bünyesindeki yetersiz sermaye

- İşletmedeki dışsal sermayenin yetersiz oluşu

\subsubsection{Bilgi Faktörleri:}


- İnovasyon çalışmalarının yetersizliği

- Kalifiye çalışan yetersizliği

- Teknoloji yetersizliği

- Pazarı tanıma güçlüğü

- Dişardan bilgi ve hizmet tedariğinde yetersizlik

- Süreç inovasyonundaki eksik işbirliği

- Pazarlama dağıtım faaliyetindeki yetersizlik

- İnovasyonda çalışanların uyumsuzluğu

- Yönetimin inovasyonu istememesi

- Girişimcinin idari fonksiyonu

- Çalışanları üretime yönlendirmeki inovasyon kusuru

\subsubsection{Pazar Faktörleri:}

- İnovasyonel ürünlerdeki talebin belirsiz oluşu

- Pazar hâkimiyeti kurulmuş piyasa

\subsubsection{Kurumsal Faktörler:}

- Tesis donanım yetersizliği

- Patent ve lisansların eksikliği

- Yasal otorite düzenlemeleri ve kapsamı

\subsubsection{Diğer Faktörler:}

- Mevcut inovasyonel süreçlerin yeterli görülmesi

- İnovasyonel ürünlerin talebinin yetersizliği.

İnovasyon yapmadaki engeller, işletmenin içinde bulunduğu sürece, firma yapısına ve dış faktörlere göre değişmektedir.

\section{Literatür Analizi:}

Çalıpınar ve Baç 'a (2007) göre, ' KOBİ'lerde İnovasyon Yapmayı Etkileyen Faktörler ve Bir alan Araştırması " konulu Ankara Bölgesinde KOSGEB veri tabanına kayıtlı gıda ve içecek sektöründe faaliyet gösteren firmalarda yapılan araştırmada, işletmede çalışan sayısı azaldıkça inovasyon sayısı da artmaktadır. İşletmedeki çalışan sayısı ve işletme yaşı ile inovasyon sayısı arasında ters yönlü bir ilişki bulunmuştur (Çalıpınar \& Baç, 2007: 445-458).

Terzioğlu, Avcı ve Gökovalı ‘ya (2008) göre, '’işletmelerde Yenilik Yeteneği: Denizli Tekstil ve Hazır Giyim Sektörü Örneği'” konulu Denizli ilinde Denizli Sanayi Odasına kayıtlı tekstil ve hazır giyim sektöründe faaliyet gösteren işletmeler arasında yapılan araştırmada, yenilikçi işletmelerin olmayanlara göre daha uzun süredir faaliyetle olduğu ve daha fazla çalışana sahip olduğu ve dolayısıyla cirolarının daha yüksek olduğu görülmüştür. İşletme yöneticisinin eğitim düzeyi yükseldikçe yenilik düzeyinin de yükseldiği belirlenmiştir. Yenilik yapma nedenleri, öncelikli olarak, ürün kalitesini arttırmak (\%67), işgücü maliyetini azaltmak (\%55), ürün çeşidini arttırmak (\%53), yurt dışında pazar payı yaratmak (\%48), üretim esnekliğini arttırmak (\%46) şeklinde etkili olduğu görülmüştür. Kaliteye önem verip kalite belgesine sahip olan işletmelerin inovasyon yapma potansiyelleri olmayanlara göre daha yüksektir (Terzioğlu vd., 2008: 377-388).

Örücü, Kılıç ve Savaş'ın (2011), 'KOBI'lerde İnovasyon Stratejileri Ve İnovasyon Yapmayı Etkileyen Faktörler: Bir Uygulama"' konulu Balıkesir Organize Sanayi Bölgesindeki araştırmasında, işletmelerin \%81,5 'inin inovasyon yaptığı, işletmelerde çalışan sayısı arttıkça inovasyon yapma eğilimin de arttığı görülmüştür. ArGe'ye ayrılan pay arttıkça inovasyon başarısının arttığı görülmüsştür. Firmaların hukuki yapılarındaki farklılık durumuna göre (örneğin anonim veya limited şirket olmaları açısından) inovasyon yapma eğilimleri üzerinde anlamlı bir ilişki bulunamamıştır (Örücü vd.,2011:14-15).

Şendoğdu ve Öztürk’e (2013) göre, 'KOBİ'lerde İnovasyon Yapma Eğilimi İle İnovasyon Performans Başarı Derecesi Arasındaki İliş̧inin Araştırılması" "konulu, Konya ilinde Konya Sanayi Odasına kayıtlı işletmeler arasından rastgele örneklemle seçilen firmalarda yapılan araştırmada, işletmenin yaşı ve çalışan sayısı ile inovasyon yapma eğilimi arasında bir ilişki bulunamamıştır. İşletmenin kendi Ar-Ge bölümünü kullanma ile inovasyon yapma arasında ilişki tespit edilmiş olup inovasyon performans başarısına etkisinin olumlu olduğu görülmüsştür (Şendoğdu \& Öztürk, 2013: 1-13).

Şahinli, Şahbaz ve Çakmak 'a (2013) göre, " Organize Sanayi Bölgesinde Girişimcilik ve İnovasyon Düzeyinin Belirlenmesi Üzerine Bir Araştırma: Karaman İli Örneği ' konulu araştırmada, Karaman Organize 
Sanayi Bölgesinde çeşitli alanlarda faaliyet gösteren işletmelerin, son beş y1lda, $\% 81,5$ 'i ürün ve süreç yeniliği yaptığı, \%59,3'ü pazarlama yeniliği yaptığı, \%63'ü organizasyonel/idari yenilik yaptığı belirlenmiştir. Yenilik için finansman kaynaklarını yetersiz bulan işletme oranı \%48,1, Ar-Ge ve yenilik için verilen desteklere ulaşmada zorluk yaşayan işletme oranı $\% 66,6$ olarak tespit edilmiştir. Ayrıca, işletme yönetimlerinin tamamı yeni fikirleri desteklemekte ve sektördeki yenilikleri takip etmektedir (Şahinli vd., 2013: 1-10).

Sabuncu 'ya (2014) göre, ' KOBİ'lerde Yenilik ve Engellerinin Tespitine Yönelik Bir Araştırma: Denizli Örneği'” konulu, Denizli ilindeki faailyet gösteren KOSGEB'e kayıtlı firmalarla yapılan araştırmada, inovasyon için yeterli fon ayrılmadığı veya finansal fonların yetersiz kaldığı, yenilik için bürokratik işlemlerin kolay olmaması ve engel teşkil ettiği görülmüştür. İçsel ve dışsal yenilik engellerinin birbirini etkilediği, engel oluşturduğu ve yenilik uygulamalarını azalttığı, inovasyon yapmayı zorlaştırdığı görülmüştür. (Sabuncu, 2014: 121).

Araştırma bulguları, Karaman ilinde faaliyet gösteren firmalara, yeni girişimcilere, inovasyon yatırımlarında yol gösterici nitelikte olup inovasyon çıktılarında, karlılıkta, üretim süreçlerinde, pazarlamada ve her türlü iş akışında inovasyonun önemi gösterecek ve işletmelerin genel başarılarında kolaylık sağlayacaktır. Ayrıca, bu konuda yapılacak araştırmalara, kaynak olacak ve literatürün zenginleşmesine katkı sağlayacaktır.

\section{Tasarım ve Yöntem:}

Günümüzde işletmelerin inovasyona eğilimleri ve yenilik arayışları her geçen gün artmaktadır. İşletmelerin inovasyon yapabilmeleri müşteri talep ve ihtiyaçlarıyla belirlenmektedir. Ayrıca, bu işletmeler inovasyon yaparken bir takım zorlukları ve engelleri de aşmak durumunda kalmaktadır.

$\mathrm{Bu}$ araştırmanın amacı, inovasyon yapma ile işletme yaşı ve işletmede çalışan sayısının inovasyona etkilerini incelemektir. İşletmenin uzun süredir faaliyette olması ve çalışan sayısının fazla olması inovasyon yapmada etkili midir sorusunun cevabı aranmıştır. Literatürde, yapılan araştırmalarda, ağırlıklı olarak işletmelerde çalışan sayısı arttıkça inovasyon yapma eğiliminin de arttığı görülmüş̧ür. Araştırmalarda, sektöre ve işletme büyüklüğüne göre, işletme yaşı ve sayısının inovasyona etkisinin olmadığı veya aralarında ters yönlü bir ilişkinin olduğu gibi farklı sonuçlara da ulaşılmıştır.

$\mathrm{Bu}$ araştırmada, inovasyon faaliyetinde bulunma nedenleri; ürün kalitesini artırmak, ürün çeşidini artırmak, piyasa payını artırmak, yeni piyasa(pazar)lar yaratmak, müşteri talep ve ihtiyaçlarını karşılamak, üretim esnekliğini geliştirmek, üretim maliyetini azaltmak ve geliri artırmak, enerji tüketimini azaltmak ve çevreye zararı azaltmak, enerji tüketimini azaltmak ve çevreye zararı azaltmak, ihracat pazarını genişletmek, markalaşma ve bilinirliği artırmak olarak belirlenmiştir.

İnovasyon yapmadaki engeller ise, riskin çok yüksek olması, yenilik maliyetlerinin çok yüksek olması, finansal kaynak yokluğu ve sermaye yetersizliği, yeterli düzeyde nitelikli kalifiye personelin yetersiz olması, yenilik konusunda müşterilerin ilgisiz olması, üst yönetimin yeniliğe olumsuz bakışı, devletin Ar-Ge inovasyon teşviklerinin yetersiz olması olarak belirlenmiştir.

Ana kütle olarak Karaman ilinde çeşitli sektörlerde faaliyet gösteren, Karaman Ticaret ve Sanayi Odasına kayıtlı işletmeler seçilmiştir. Firma büyüklügüü, sektörü ve yapısı gözetilmeden evrenden rastgele örneklem seçimi ile firmalar belirlenerek ziyaret edilmiş ve yüz yüze görüssme yapılmıştır. Karaman Organize Sanayi Bölgesinde aktif faaliyet gösteren 94 adet işletmeye, Karaman il merkezindeki toplam 218 sanayi işletmesinden toplamda 108 adet işletmeye/firmaya ulaşılabilmiştir.

Araştırma için gerekli verilerin elde edilmesinde anket yöntemi kullanılmıştır. Ankette inovasyonun kısa bir tanımı yapılarak bilgi verilmiş ve anlaşılmayan sorularda açıklama yapılmak suretiyle tam katılımla tüm sorulara hatasız cevaplar alınarak sağ lıklı veriler elde edilmiştir. Nicel veri toplama yöntemi ile mart, nisan, mayıs 2016 tarihinde 108 adet işletmeden anket uygulaması ile veriler toplanmıştır. Ankette 5'li likert tipi ölçekle sorular oluşturulmuş, inovasyon tutumları, inovasyon düzeyleri, işletmenin demografik özellikleri ve inovasyon eğilimleri belirlenmiştir. İnovasyon yapma nedenleri ve engelleri elde edilen veriler ışığında istatistik olarak yorumlanmıştır.

Anket sonuçları SPSS 20.0 istatistik veri analiz programı ile değerlendirilmiştir. Non-parametrik testler KiKare ve parametrik testler Doğrusal Regresyon ve T-Testi şeklinde frekans analizleri ile uygulanmıştır. İnovasyona karşı tutum ve inovasyon düzeyleri için Kolmogorow-Smirnov ve Shapiro-Wilk normallik testleri uygulanmıştır. Testte, dağılımın normal olmadığı ve puanlarda değişkenlik gösterdiği görülmüştür. Ölçeğin Cronbach’s Alpha güvenirlik puanı 0.90 olup yüksek düzeyde çıkmıştır. Araştırmada bağımlı değişken olarak inovasyon yapma, bağımsız değişken olarak işletme yaşı ve işletmede çalışan sayısı belirlenmiştir. Belirlenen hipotezler test edilmiştir.

Araştırmada, inovasyon faaliyetinde bulunma nedenlerine ilişkin dağılım tablosu aşağıdaki gibidir: 
Tablo1. İnovasyon Faaliyetinde Bulunma Nedenleri

\begin{tabular}{|l|c|c|c|c|c|}
\hline & $\begin{array}{c}\text { Hiç } \\
\text { onemli } \\
\text { değil }\end{array}$ & Önemsiz & Az önemli & Önemli & Çok önemli \\
\hline Ürün kalitesini artırmak & 2 & 13 & 16 & 33 & $* 44$ \\
\hline Ürün çeşidini artırmak & 2 & 13 & 16 & 33 & $* 44$ \\
\hline Piyasa payını artırmak & 0 & 0 & 6 & 35 & $* 67$ \\
\hline Yeni piyasa(pazar)lar yaratmak & 0 & 4 & 4 & 33 & $* 67$ \\
\hline Müşteri talep ve ihtiyaçlarını karşılamak & 0 & 3 & 10 & 20 & $* 75$ \\
\hline Üretim esnekliğini geliştirmek & 8 & 17 & 25 & 27 & $* 31$ \\
\hline $\begin{array}{l}\text { Üretim maliyetini azaltmak ve geliri } \\
\text { artırmak }\end{array}$ & 4 & 13 & 19 & 24 & $* 48$ \\
\hline $\begin{array}{l}\text { Enerji tüketimini azaltmak ve çevreye } \\
\text { zararı azaltmak }\end{array}$ & 9 & 14 & 25 & 22 & $* 38$ \\
\hline İhracat pazarını genişletmek & 18 & 15 & 8 & 10 & $* 57$ \\
\hline Markalaşma ve bilinirliği artırmak & 1 & 4 & 11 & 28 & $* 64$ \\
\hline *mod & & & & \\
\hline
\end{tabular}

İnovasyon faaliyetinde bulunma nedenlerine bakıldığında, her bir maddenin her katılımcı için ağırlıklı olarak "çok önemli' şeklinde ifade edildiği görülmektedir. Bunun yanında, maddeler arasında bir önem sırası yapmak gerekirse, müşteri talep ve ihtiyaçlarını karşılamak en sık şekilde 'çok önemli'" olarak ifade edilirken (75 kişi), üretim esnekliğini geliştirmek faktörünü '"çok önemli', olarak ifade eden yalnızca 31 kişidir.

Araştırmada, inovasyon yapmayı engelleyen faktörlerin dağılımı ise Tablo 2'deki gibidir:

Tablo 2. İnovasyon Faaliyetinde Bulunmayı Engelleyen Nedenler

\begin{tabular}{|l|c|c|c|c|c|}
\hline & $\begin{array}{c}\text { Hiç etkili } \\
\text { değil }\end{array}$ & Az etkili & Orta etkili & Etkili & $\begin{array}{c}\text { Çok } \\
\text { etkili }\end{array}$ \\
\hline Riskin çok yüksek olmas1 & 6 & 18 & $38^{*}$ & 31 & 15 \\
\hline Yenilik maliyetlerinin çok yüksek olması & 4 & 4 & 29 & $* 49$ & 23 \\
\hline Finansal kaynak yokluğu ve sermaye yetersizliği & 13 & 13 & 22 & 25 & $* 35$ \\
\hline $\begin{array}{l}\text { Yeterli düzeyde nitelikli kalifiye personelin yetersiz } \\
\text { olması }\end{array}$ & 3 & 17 & 28 & $* 34$ & 26 \\
\hline Yenilik konusunda müşterilerin ilgisiz olması & 16 & 26 & $* 45$ & 15 & 6 \\
\hline Üst yönetimin yeniliğe olumsuz bakışı & $* 41$ & 29 & 21 & 11 & 6 \\
\hline $\begin{array}{l}\text { Devletin Ar-Ge inovasyon teşviklerinin yetersiz } \\
\text { olması }\end{array}$ & 21 & $* 30$ & $* 37$ & 10 & 10 \\
\hline$*$ mod & & & & 10 \\
\hline
\end{tabular}

Engelleyici faktörlere bakıldığında, katılımcılar, finansal kaynak yokluğunun en 'çok etkili' bir engelleyici sebep olduğunu belirtmişlerdir. Bunun yanında, yenilik maliyetlerinin yüksek oluşu ve yeterli uygun kalifiye personelin bulunmaması yüksek düzeyde "'etkili" faktörlerken, riskin çok yüksek olması ve yenilik konusunda müşterilerin ilgisizliği ' 'orta" düzeyde etkilidir. Üst yönetimin yeniliğe olumsuz bakışı ise ağırlıklı olarak "'etkili değil"' şeklinde ifade edilmiştir.

\section{Hipotezlerin Test Edilmesi:}

H1: İşletme yaşı ile inovasyon yapma arasında anlamlı bir ilişki vardır.

Değişkenler kategorik olduğundan, non-parametrik test olan Ki-Kare testi gerçekleştirilmiştir. Teste ilişkin bulgular Tablo 3'deki gibidir.

Tablo 3. İşletme Yaşı ile İnovasyon Yapma Arasındaki İlişki

\begin{tabular}{|l|c|c|c|c|c|c|c|}
\hline Gruplar & & \multicolumn{2}{|c|}{ İnovasyon yapma } & \multirow{2}{*}{ Toplam } & \multirow{2}{*}{ X2 } & \multirow{2}{*}{ sd } & p \\
\hline & & Evet & Hayır & & & & \\
\hline & $1-5 \mathrm{y} 1 \mathrm{l}$ & 15 & 5 & 20 & 6,251 & 4 & 0,181 \\
\cline { 2 - 8 } & $6-10 \mathrm{y} 1 \mathrm{l}$ & 14 & 17 & 31 & & & \\
\hline
\end{tabular}


Uluslararası Yönetim İktisat ve İşletme Dergisi, ICMEB17 Özel Sayısı

Int. Journal of Management Economics and Business, ICMEB17 Special Issue

\begin{tabular}{|l|c|c|c|c|c|c|c|}
\hline \multirow{2}{*}{$\begin{array}{l}\text { İşletmeniz kaç } \\
\text { yıldır faaliyet } \\
\text { gösteriyor }\end{array}$} & $11-15$ yıl & 6 & 3 & 9 & & & \\
\cline { 2 - 8 } & $16-20$ yıl & 12 & 6 & 18 & & & \\
\hline & 20 yıl ve üstü & 21 & 9 & 30 & & & \\
\hline
\end{tabular}

Şekil 2. İşletme Yaşı ve İnovasyon Grafiği

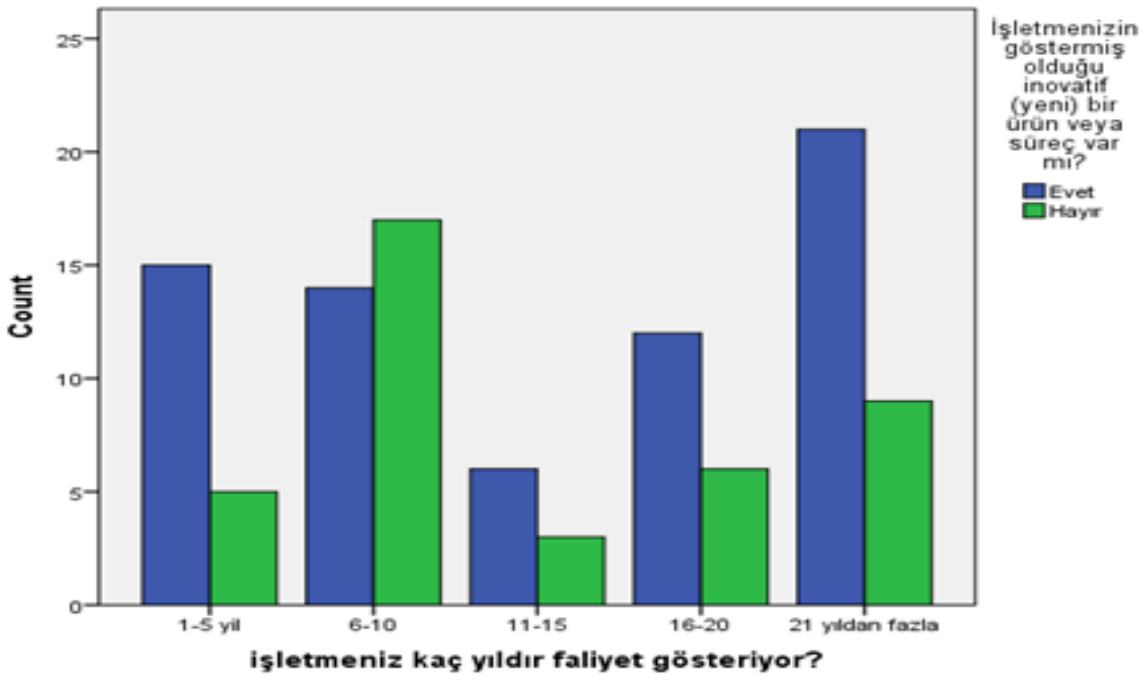

Tablo 3'te görüldüğü gibi, p değeri 0,05 ’ten büyük olduğu için, işletme yaşı ile inovasyon yapma durumu arasında istatistiksel olarak anlamlı bir ilişki bulunmamaktadır. En az beş yıllık işletmelerin inovasyon yapma oranı \%22 iken, en az yirmi yıldır faaliyette olan işletmelerin inovasyon yapma oranı \%30 olduğu görülmektedir. İşletmelerin \%63’ü inovasyon yapmaktadır.

H2: İşletmede çalışan sayısı ile inovasyon yapma arasında anlamlı bir ilişki vardır.

Değişkenler kategorik olduğundan, non-parametrik test olan Ki-Kare testi gerçekleştirilmiştir. Teste ilişkin bulgular Tablo 4'teki gibidir:

Tablo 4. Çalışan Sayısı ile İnovasyon Yapma Arasındaki İlişki

\begin{tabular}{|c|c|c|c|c|c|c|c|}
\hline \multirow[t]{2}{*}{ Gruplar } & & \multicolumn{2}{|c|}{ İnovasyon yapma } & \multirow{2}{*}{ Toplam } & \multirow{2}{*}{$\mathbf{X} 2$} & \multirow{2}{*}{ sd } & \multirow{2}{*}{$\mathbf{p}$} \\
\hline & & Evet & Hayır & & & & \\
\hline \multirow{5}{*}{$\begin{array}{l}\text { İşletmenizde kaç } \\
\text { kişi çalışıyor? }\end{array}$} & 1-10 kişi & 9 & 13 & 22 & 24,380 & 4 & 0,000 \\
\hline & $11-50$ & 21 & 22 & 43 & & & \\
\hline & $51-100$ & 11 & 5 & 16 & & & \\
\hline & $101-249$ & 8 & 0 & 8 & & & \\
\hline & 250 ve üstü & 19 & 0 & 19 & & & \\
\hline TOPLAM & & 68 & 40 & 108 & & & \\
\hline
\end{tabular}

Şekil 3. Çalışan Sayısı ve İnovasyon Grafiği

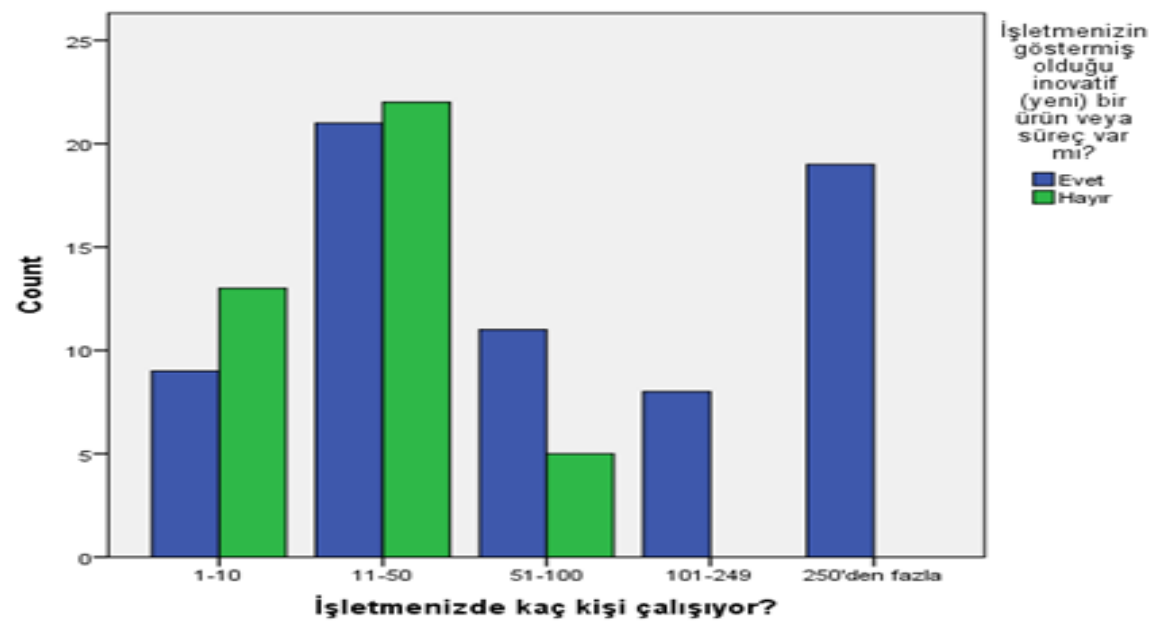


İşletmede çalışan sayısı ile inovasyon yapma arasında istatistiksel olarak anlamlı bir ilişki bulunmaktadır. İşletmede çalışan sayısının fazla olması dolaylı olarak inovasyon yapmayı olumlu etkilediği tespit edilmiştir. İkiyüzelli ve üstü çalışanı olan işletmelerdeki inovasyon yapma oranı $\% 27$ iken, 11-50 kişi aralığında çalışanı olan işletmelerin inovasyon yapma oranı $\% 30$ olduğu görülmektedir. Buna göre, ağırlıklı olarak işletmenin çalışan sayısı arttıkça, faaliyet büyüklüğünden dolayı inovasyon yapma ihtimalinin de artabileceği düşünülmektedir.

\section{Araştırmanın Kısıtları:}

Araştırma için seçilen bölgenin sadece Karaman ili ile sınırlı olması en önemli kısıtllılıktır. İşletmelerde ankete katılımdaki isteksizlik ve teşvik edici unsurların yetersiz oluşu da daha fazla firmaya ulaşabilmeyi engellemiş̧ir.

\section{Bulgular ve Tartışma:}

Araştırmadan elde edilen bulgular şu şekildedir:

Tablo 5. İşletmelerde Çalışan Sayısı

\begin{tabular}{|c|c|c|}
\hline İşletmenizde kaç kişi çalışıyor? & N & 20,4 \\
\hline $1-10$ kişi & 22 & 39,8 \\
\hline $11-50$ kişi & $* 43$ & 14,8 \\
\hline $51-100$ kişi & 16 & 7,4 \\
\hline $101-249$ kişi & 8 & 17,6 \\
\hline 250 kişi ve üstü & 19 & 100 \\
\hline TOPLAM & 108 & \\
\hline
\end{tabular}

\section{Şekil 4. İşletmede Çalışan Sayısı Grafiği}

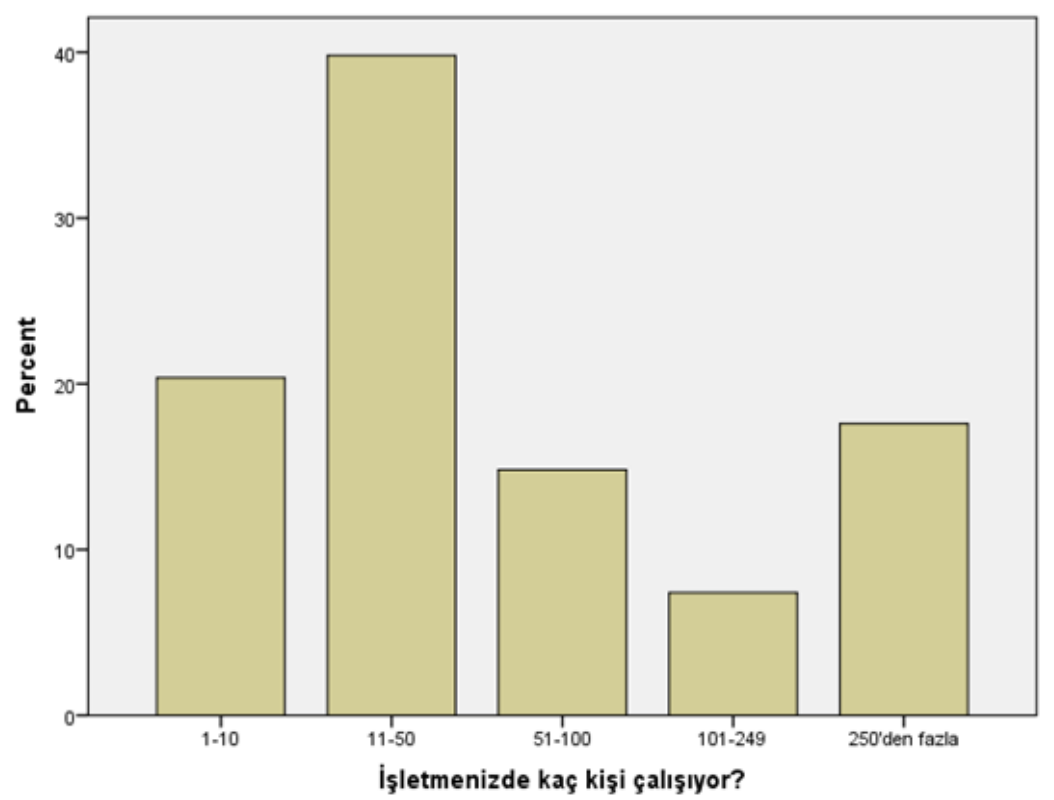

İşletmelerin çalışan sayılarına ilişkin dağılıma bakıldığında (Tablo 5), büyük çoğunluğunun (\%39,8) 11-50 çalışana sahip olduğu, 250 kişi ve üstü çalışana sahip işletmelerin ise yalnızca \%17,6'sını oluşturduğu görülmektedir.

Bu bölümde işletmeler ve katılımcılara ilişkin bilgilerin dağılım (frekans) tabloları verilmiştir. Tablo 6'da işletmelerin faaliyet sürelerine göre dağılımı gösterilmektedir. 
Tablo 6. İşletmenin Faaliyet Süresi

\begin{tabular}{|c|c|c|}
\hline İşletmeniz kaç yıldır faaliyet gösteriyor? & $\mathbf{N}$ & $\mathbf{\%}$ \\
\hline $0-5$ y1l & 20 & 28,7 \\
\hline $6-10$ y1l & $* 31$ & 8,3 \\
\hline $11-15$ y1l & 9 & 16,7 \\
\hline $16-20$ y1l & 18 & 27,8 \\
\hline 21 yıldan fazla & 30 & 100 \\
\hline TOPLAM & 108 & \\
\hline$* \bmod$ & & \\
\hline
\end{tabular}

\section{Şekil 5. İşletmenin Faaliyet Süresi Grafiği}

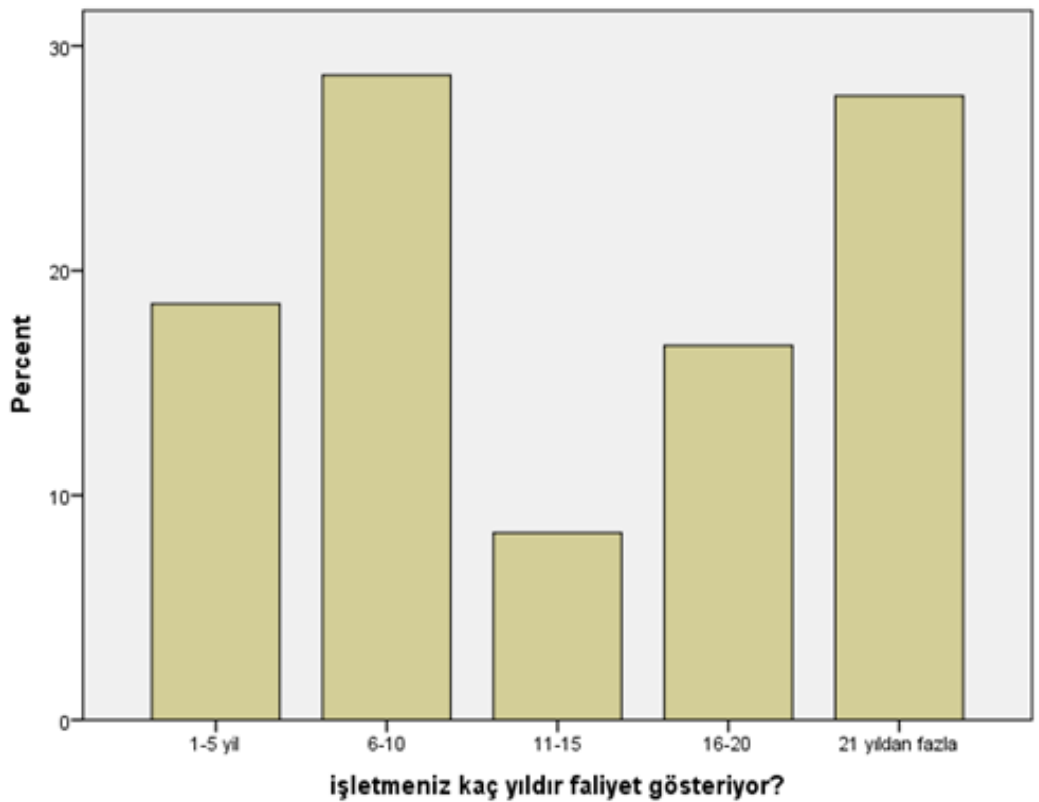

Çalışmaya katılan işletmelerin ağırlıklı olarak 6-10 yıllık işletmelerden oluştuğu (\%28,7), bunun yanında en sık karşımıza çıkan ikinci yoğunluktaki işletme faaliyet yılının ise 21 yıl ve üzeri olduğu $(\% 27,8)$ görülmektedir.

Türk Patent ve Marka Kurumu veri tabanına kayıtlı verilerden elde edilen, yıllara yaygın Karaman iline ait son on yıllık "'patent, faydalı model ve marka" başvuru ve tescillerinin rakamsal istatistikleri aşağıdadır:

Tablo 7. Karaman iline ait Patent, Faydalı Model, Marka Sayıları

\begin{tabular}{|c|c|c|c|c|c|c|c|c|c|c|c|}
\hline \multicolumn{12}{|c|}{ PATENT BAŞVURULARININ İLLERE GÖRE DAĞILIMI } \\
\hline & Yillar & \multirow{2}{*}{2007} & \multirow[t]{2}{*}{2008} & \multirow[t]{2}{*}{2009} & \multirow{2}{*}{2010} & \multirow{2}{*}{2011} & \multirow{2}{*}{2012} & \multirow{2}{*}{2013} & \multirow{2}{*}{2014} & \multirow{2}{*}{2015} & \multirow[t]{2}{*}{2016} \\
\hline İl kodu & & & & & & & & & & & \\
\hline 70 & KARAMAN & 1 & 0 & 2 & 2 & 2 & 4 & 7 & 4 & 7 & 9 \\
\hline & \multicolumn{11}{|c|}{ PATENT TESCILLERININ İLLERE GÖRE DAĞILIMI } \\
\hline & Yillar & \multirow[t]{2}{*}{2007} & \multirow[t]{2}{*}{2008} & \multirow[t]{2}{*}{2009} & \multirow[t]{2}{*}{2010} & \multirow[t]{2}{*}{2011} & \multirow[t]{2}{*}{2012} & \multirow[t]{2}{*}{2013} & \multirow[t]{2}{*}{2014} & \multirow[t]{2}{*}{2015} & \multirow[t]{2}{*}{2016} \\
\hline İl kodu & & & & & & & & & & & \\
\hline 70 & KARAMAN & 0 & 0 & 0 & 0 & 0 & 0 & 0 & 1 & 1 & 5 \\
\hline \multicolumn{12}{|c|}{ FAYDALI MODEL BAȘVURULARININ ILLERE GÖRE DAĞILIMI } \\
\hline & Yillar & \multirow[t]{2}{*}{2007} & \multirow[t]{2}{*}{2008} & \multirow{2}{*}{2009} & \multirow[t]{2}{*}{2010} & \multirow{2}{*}{2011} & \multirow{2}{*}{2012} & \multirow[t]{2}{*}{2013} & \multirow{2}{*}{2014} & \multirow{2}{*}{2015} & \multirow[t]{2}{*}{2016} \\
\hline İl kodu & & & & & & & & & & & \\
\hline 70 & KARAMAN & 2 & 2 & 4 & 1 & 4 & 5 & 2 & 6 & 5 & 3 \\
\hline
\end{tabular}




\begin{tabular}{|c|c|c|c|c|c|c|c|c|c|c|c|}
\hline & Yillar & \multirow[t]{2}{*}{2007} & \multirow[t]{2}{*}{2008} & \multirow[t]{2}{*}{2009} & \multirow[t]{2}{*}{2010} & \multirow[t]{2}{*}{2011} & \multirow[t]{2}{*}{2012} & \multirow[t]{2}{*}{2013} & \multirow[t]{2}{*}{2014} & \multirow[t]{2}{*}{2015} & \multirow[t]{2}{*}{2016} \\
\hline \multicolumn{2}{|l|}{ İl kodu } & & & & & & & & & & \\
\hline 70 & KARAMAN & 6 & 3 & 2 & 1 & 2 & 3 & 3 & 4 & 3 & 2 \\
\hline \multicolumn{12}{|c|}{ MARKA BAŞVURULARININ İLLERE GÖRE DAĞILIMI } \\
\hline & Yıllar & 2007 & 2008 & 2009 & 2010 & 2011 & 2012 & 2013 & 2014 & 2015 & 2016 \\
\hline \multicolumn{12}{|l|}{ İl kodu } \\
\hline 70 & KARAMAN & 209 & 158 & 207 & 168 & 259 & 221 & 233 & 201 & 406 & 261 \\
\hline \multicolumn{12}{|c|}{ MARKA TESCILLERININ İLLERE GÖRE DAĞILIMI } \\
\hline & Yillar & 2007 & 2008 & 2009 & 2010 & 2011 & 2012 & 2013 & 2014 & 2015 & 2016 \\
\hline \multicolumn{12}{|l|}{ İl kodu } \\
\hline 70 & KARAMAN & 167 & 149 & 147 & 113 & 118 & 139 & 142 & 185 & 220 & 427 \\
\hline
\end{tabular}

Kaynak: Türk Patent ve Marka Kurumu (Turkpatent)

Bilim, Sanayi ve Teknoloji Bakanlığı, Türk Patent ve Marka Kurumuna yapılan marka başvuru ve tescil rakamlarına Türkiye genelinde (2016 yılına) bakıldığında, yerli marka başvuru sayısı geçen yıla göre $\%$ - 4,93 oranla düşmüş, yerli patent başvuruları \% 16,93 oranında artmıştır.

Karaman ilinde fikri, sınai ve mülkiyet hakları açısından tescillerin yeterli ve istenilen seviyede olmadığ görülmektedir. Karaman ilinin, bakliyat-hububat, ağaç-orman ürünleri, mobilya ve gıda sektöründe, bisküvi sektöründe önemli bir üretim merkezi konumunda olmasından dolayı KOBİ'lerin cirolarının arttırmasının yolu satış-pazarlama stratejilerini koşullara göre iyileştirerek inovatif çalışmalarla gelişmiş ve daha büyük işletmelere dönüşmeleri gerekmektedir. Ar-Ge ve yatırım teşviklerinden yeterince yararlanılamadığı, işletmelerin rekabetçilik düzeyinin arttırılması ve katma değeri yüksek ürünler elde etmeleri için inovasyona daha fazla önem vermeleri dolayısıyla markalaşma faaliyetlerini arttırmaları gerekmektedir (MEVKA, 2014-2023 Konya Karaman Ar-Ge ve İnovasyon Strateji Belgesi Taslak Bölge Planı).

Yaptığımız araştırma sonuçlarıyla doğrusal olarak, işletmelerin nerdeyse tamamının inovasyon yapma hevesi isteği içinde olduğu bulgusuyla, yukarıdaki tabloda görüldüğü üzere yıllara göre marka tescillerinin (çıktılarının) olumlu yönde arttığı, yükselen bir eğilim içerisinde olduğu gözlemlenmiştir.

\section{Sonuç ve Öneriler:}

Araştırmaya konu Karaman ilindeki 108 adet işletme üzerinde yapılan çalışma sonucunda, işletmelerde inovasyon yapma ile işletmenin yaşı arasında anlamlı bir ilişki tespit edilememiştir. H1 hipotezinde p değeri 0,05 'ten büyük olduğu için, işletme yaşı ile inovasyon yapma durumu arasında istatistiksel olarak anlamlı bir ilişki bulunamamıştır. H2 hipotezinde işletmede çalışan sayısı ile inovasyon yapma arasında istatistiksel olarak anlamlı bir ilişki bulunmuştur. İşletmedeki çalışan sayısının inovasyon yapmayı olumlu etkilediği görülmüştür.

Firma özelliklerine göre daha önce yapılmış olan araştırma sonuçları değişken sonuçlar vermiştir. Ağırlıklı olarak çalışan sayısı arttıkça inovasyon yapma sayısının arttığı ve firma faaliyetleri genişledikçe bununla doğrusal olarak büyümenin oluştuğu ve inovasyon eğiliminin arttı̆̆ görülmüştür. Karaman ilinde yapılan araştırmada, ağırlıklı olarak, işletme yaşı genç 10 yıldan az olan işletmeler ile işletme yaşı 20 yıldan fazla olan işletmelerin inovasyon yapma faaliyetleri daha yüksek olup inovasyon eğilimlerinin fazla olduğu görülmüştür. İşletmede çalışan sayısı 11-50 kişi aralığında olan işletmeler ile 250'den fazla çalışanı olan işletmelerin inovasyon yapma eğilimlerinin daha yüksek olduğu görülmüştür. Buradan hareketle, büyümeyle beraber çalışan sayısı artmakta dolayısıyla işletme kurumsallaştıkça Ar-Ge'ye yapılan yatırımlar artmakta ve departmanlarda fonksiyonel uzmanlaşma ve işbirliği artmaktadır. Bu durumun inovasyon başarısına olumlu etkisi olduğu düşünülmektedir. Ayrıca, işletme yaşı genç ve modern teknoloji ile üretim yapan işletmelerin hareket kabiliyeti daha esnek ve yüksek olup inovasyon başarısı daha kuvvetlidir.

Araştırmanın kısıtı, sadece Karaman ilinde yapılmış olması ve bölgesel olarak sınırlı kalmasıdır. Bölgesel araştırmalar farklılık oluştursa da temelde, inovasyon etki eden faktörleri içsel ve dişsal faktörler olarak gruplandırabiliriz. İçsel faktörler ağırlıklı olarak firma özellikleri/yetenekleri ve yönetimsel/kültürel özelliklere göre oluşmaktadır. Dışsal faktörler ise, sektör, pazar yapısı, kamusal düzenlemeler ve desteklere göre oluşmaktadır. Yeni pazarlar oluşturmak ve yeni girişimler yapabilmek için inovasyona etki eden faktörler iyi analiz edilmeli ve stratejik kararlar belirlenmelidir. Yeni araştırmacılara ve işletmelere şu öneriler verilebilir: Farklı illerde ve bölgesel-sektörel olarak genişletilerek yapılan daha kapsamlı genel bir araştırma daha farklı sonuçlar ortaya çıkarabilir. Firmaların inovasyon tutumları ve inovasyon düzeyleri daha kapsamlı incelenebilir. İşletmenin KOBİ ve kurumsal ölçekte firma olmasına göre elde edilen sonuçlar değişkenlik gösterebilir. Bu araştırma, inovasyon konusunda istekli olup inovasyon yapmak isteyen firmalara, inovasyon yapma nedeni ve karşılacağı 
engeller konusunda yol gösterici bir rehber olacaktır. Firma yöneticileri elde edilen sonuçlara bakarak, işletmelerine yeni yatırım yapmada rahatlıkla rasyonel kararlar verebilecektir. Anketten elde edilen bulgular yenilik-değişim sürecinde girişimde bulunmada firmalara karar verdirici bir model sunmaktadır. Yenilik yapma potansiyeli olan firmalar girişim konusunda cesaretlendirilmeli, inovasyon teşvikleri arttırılmalıdır. İşletmelerin inovasyon kabiliyetleri, yüksek kar marjları elde edebilmek ve yeni pazarlar oluşturabilmek için marka-patentlerle güvence altına alınmalı ve işletmelerde farkındalık oluşturulmalıdır. İstihdamın arttırılmasında, işletmelerdeki verimliliğin ve başarının yükseltilmesinde inovasyonel süreçler büyük önem taşımaktadır. Rekabet gücünün ve karlılığın sürdürülebilir olmasında inovasyon ve sürekli değişim kaçınılmaz bir zorunluluk haline gelmektedir.

\section{Kaynakça:}

Arslan, K. (2008). Küresel Rekabet Baskısı Altında Tekstil ve Hazır Giyim Sektörünün Dönüşüm Stratejileri ve Yeni Yol Haritası. MÜSİAD Araştırma Raporlar 57, 2008, İstanbul, 104.

Çalıpınar, H. \& Baç, U. ( 2007 ). Kobi'lerde İnovasyon Yapmayı Etkileyen Faktörler ve Bir Alan Araştırması. Ege Akademik Bakış, 7 (2), 445-458.

Elçi, Ş. (2006). Inovasyon: Kalkınmanın ve Rekabetin Anahtarı, (7.Baskı), Meteksan Bilişim Grubu, BT Haber, 27-150.

Freeman, C. \& ve Soete, L. (2004). Yenilik İktisadl, (5.Basım), (Çeviren: Ergun Türkcan), Ankara: TÜBİTAK Yayınlar1, 231-398.

Küresel İnovasyon Endeksi 2017 Raporu, (2017). Cornell Üniversitesi, INSEAD ve Dünya Fikri Mülkiyet Örgütü (WIPO). Erişim Tarihi: 23.09.2017,

http://www.wipo.int/edocs/pubdocs/en/wipo_pub_gii_2017.pdf

MEVKA. (2014). 2014-2023 Konya Karaman Ar-Ge ve Ínovasyon Strateji Belgesi Taslak Bölge Planı, Erişim Tarihi: 23.09.2017, http://aksehirtso.org.tr/uploaded/dosya/AR\%20GE\%20VE\%20\%C4\%B0NOVASYON.pdf

OECD-EUROSTAT. (2005). Oslo Kılavuzu, Yenilik Verilerinin Toplanması ve Yorumlanması Iç̧in İlkeler, (3.Baskı), (Çeviren: Tübitak), Paris: Oecd ve Eurostat Ortak Yayımı, 50-117.

Örücü, E., Kılıç, R., \& Savaş, A. ( 2011), Kobilerde Inovasyon Stratejileri ve İnovasyon Yapmayı Etkileyen Faktörler: Bir Uygulama. Doğuş Üniversitesi Dergisi, 12(1),1-73. Erişim Tarihi: 23.09.2017, http://openaccess.dogus.edu.tr/bitstream/handle/11376/248/orucu.pdf?sequence=1

Sabuncu, B. (2014), Kobi’lerde Yenilik ve Engellerinin Tespitine Yönelik Bir Araştırma: Denizli Örneği. Işsletme Araştırmaları Dergisi, 1-21.

Şahinli, M.A., Şahbaz, N., \& Çakmak, Y. (2013). Organize Sanayi Bölgesinde Girişimcilik ve İnovasyon Düzeyinin Belirlenmesi Üzerine Bir Araştırma: Karaman İli Örneği. Unikop, 1-10.

Şendoğdu A.A., \& Öztürk Y.E.. (2013). Kobi’lerde İnovasyon Yapma Eğilimi İle İnovasyon Performans Başarı Derecesi Arasındaki İlişkinin Araştırılması. Niğde Üniversitesi IIIBF Dergisi, 6 (2), 1-13.

Terzioğlu, M., Avcı, M., \& Gökovalı, U. (2008). İşletmelerde Yenilik Yeteneği: Denizli Tekstil ve Hazır Giyim Sektörü Örneği. Ç.Ü. Sosyal Bilimler Dergisi, (17), 3, 377-388.

Trott, P. (2005). Innovation Management and New Product Developmant. 3rd, Prantice Hall Inc. USA, 15.

Turanlı, R., \& Sarıdoğan, E. (2010). Bilim-Teknoloji-Inovasyon Temelli Ekonomi ve Toplum, İstanbul: İTO Yayınları, 14-15.

Westland, J.C. (2008). Global Innovation Management, A Strategic Approach. Palgrave Macmillan, 8.

$\begin{array}{lllll}\text { www.abigem.org. } & \text { 23.09.2017. }\end{array}$ http://www.abigem.org/appmanager/tr/portal?_nfpb=true\&_pageLabel=pageKobiTeknoloji\&nodeName= KobiTeknoloji_04

www.fka.gov.tr. FKA. (2010). Güravşar Gökçe, S. İnovasyon Kavramı ve İnovasyonun Önemi. Erişim Tarihi: 23.09.2017.

http://fka.gov.tr/sharepoint/userfiles/Icerik_Dosya_Ekleri/FIRAT_AKADEMI/\%C4\%B0NOVASYON\% 20KAVRAMI\%20VE\%20\%C4\%B0NOVASYONUN\%20\%C3\%96NEM\%C4\%B0.pdf

www.kosgeb.gov.tr. KOSGEB. (Mart 2016). AR-GE, Inovasyon ve Endüstriyel Uygulama Destek Programı. Erişim Tarihi: 23.09.2017. http://kosgeb.gov.tr/Content/Upload/Dosya/Endustriyel/ArGe_\%C4\%B0novasyon_ve_End\%C3\%BCstriyel_Uygulama_Destek_Program\%C4\%B1_(05).pdf 
Uluslararası Yönetim İktisat ve İşletme Dergisi, ICMEB17 Özel Sayısı Int. Journal of Management Economics and Business, ICMEB17 Special Issue

$\begin{array}{lllll}\text { www.northstarinnovation.com.tr. } & \text { (2015). Inovasyon. } & \text { Erişim } & \text { Tarihi: } & \text { 23.09.2017. }\end{array}$ http://northstarinnovation.com.tr/inovasyon.html

www.smenetworking.gov.tr. Başer, B. C., Yılmaz, A., \& İyiler, Z. (2016). Kümeler İçin İnovasyon ve Ar-Ge Yönetimi Kllavuzu. Erişim Tarihi: 23.09.2017. http://www.smenetworking.gov.tr/userfiles/pdf/belgeler/ekonomiBakanligi/8_inovasyon.pdf

www.tuik.gov.tr. TÜIK (Türkiye İstatistik Kurumu). (Ekim 2015). Yenilik Araştırması, 2014. Erişim Tarihi: 23.09.2017. http://www.tuik.gov.tr/PreHaberBultenleri.do?id=18662

www.tuik.gov.tr. TÜIK (Türkiye İstatistik Kurumu). (Kasım 2015). Küçük ve Orta Büyüklükteki Girişim İstatistikleri, 2015. Erişim Tarihi: 23.09.2017. www.tuik.gov.tr/HbPrint.do?id=21864

http://www.turkpatent.gov.tr. (Turkpatent). (2016). Resmi İstatistikler, Erişim Tarihi: 23.09.2017. http://www.turkpatent.gov.tr/TurkPatent/statistics/

Yapar, İ. (2015). Kobilerde Inovasyon ve İnovasyonun Önemi: Kayseri İli Örneği, Yüksek Lisans Tezi, Niğde Üniversitesi Sosyal Bilimler Enstitüsü, Niğde. 